Article Type: Research Paper

\title{
The Analysis of Clearance and Ports Equipment Toward Long Container Dwelling Time (Case Study: KPP Bea Cukai Tanjung Emas and Semarang Container Terminal)
}

\author{
Erita Utami, Endang Sulistiyani*, and Azizah
}

\section{OPEEN}

\section{AFFILIATION: \\ Jurusan Administrasi Bisnis, Politeknik Negeri Semarang. Semarang. Indonesia. \\ *CORRESPONDENCE: \\ endangsulis980@gmail.com}

THIS ARTICLE IS AVALILABLE IN:

http://journal.umy.ac.id/index.php/mb

DOI: 10.18196/mb.11183

\section{CITATION:}

Utami, E., Sulistiyani, E., \& Azizah. (2020). The Analysis of Clearance and Ports Equipment Toward Long Container Dwelling Time (Case Study: KPP Bea Cukai Tanjung Emas and Semarang Container Terminal). Jurnal Manajemen Bisnis, 11(1), $1-12$.

Received: 28 November 2019

Accepted: 24 April 2020

\begin{abstract}
The aim of this study is to examine the effect of clearance and port equipment on long container dwelling time both partially and simultaneously. The study utilized quantitative research method. Secondary data which used were monthly period data from January 2016 - March 2019. The data sources were from PT. Pelabuhan Indonesia III (Persero) Semarang Container Terminal and Tanjung Emas Custom and Excises. Regarding the use of period, the total data which used is thirty-nine months. The study explored with multiple linear regression statistical analysis. The t-Test result informed that clearance has significant effect on long container dwelling time. Meanwhile, the port equipment has no significant effect on long container dwelling time. Both clearance and port equipment has significant effect simultaneously. Clearance gives a dominant influence on container waiting time From the result, suggestions that can be taken are conducting the Focus Group Discussion of Indonesia National Single Window, add more equipment, avoid the breakdown equipment together with maintenance schedule, provide operator training, and benchmark to other port companies.
\end{abstract}

Keywords: Clearance; Dwelling Time; Port Equipment; Ports.

\section{Introduction}

The trade sector of Indonesia in the latest year has significantly increased year by year, especially in export and import. It proves because according to the Trade Ministry statistic, Indonesia trade balance touched up to $13 \%$ in 2018 and within the world trading, 77\% are the contribution of seaborne according to UNTCAD (2017). The dominant of seaborne encourage every country to build and develop their services at port.

One of the strategies to make a better port is to improve and develop the services of the ports. Therefore, ports management is needed to direct the development of services which are more effective and efficient in order to make the service performance of ports faster and more professionals. Ports engage in various activities: loading/discharging cargo onto/from vessels; providing value-added services such as labeling, packaging, cross-docking, and others; and acting as warehouse and distribution centers (World Bank, 2007). 
Utami, Sulistiyani, \& Azizah

The Analysis of Clearance and Ports Equipment Toward Long Container Dwelling Time...

Table 1 Dwelling Time 2013-2018

\begin{tabular}{|cc|}
\hline Year & Dwelling Time (days) \\
\hline 2014 & 6.24 \\
2015 & 6.42 \\
2016 & 6.41 \\
2017 & 4.19 \\
2018 & 5.37 \\
\hline Average & 5.7 \\
\hline
\end{tabular}

Source: Semarang Container Terminal, 2018

Nevertheless, the problems always found in every port in Indonesia, such as the longtime to process the clearance and dwelling time, including the Semarang Container Terminal as one of the international terminals in Indonesia. According to the company data from $2013-2018$, the average of dwelling time in Semarang Container Terminal is 5.7 days.

As the result, the number of dwelling time is violated the rules of government. According to Peraturan Menteri No PM 116 in 2016, the number of dwelling time in international port in Indonesia maximum 3 (three) days since staking the container. The problem of Semarang Container Terminal above shows that the performance of the port is not satisfying enough as one of the international container terminal in Indonesia. Dwelling time can be a big problem for ports and trading activities. The number of the container will increase in container yard and can cause the overload capacity that will lead to obstruction for other container and also there will be no space for the upcoming containers.

According to Trade Ministry (2016) the cause of the increasing dwelling time in ports terminology most of them caused by the facilities of ports such as less capacity of container yard, road stuck, difficult bureaucracy, long procedures that must be done, costs, utilities of ports equipment and ports storage that usually used by the businessmen to stake their containers. Long procedures that usually assumed as the cause of dwelling time is the flow of import permit or clearance process such as pre clearance, custom clearance, and post clearance. Those permissions need a long time to process.

Port facilities take an important role in port performance. All activities that happen in port need supporting from port facilities. Facilities can be the main key to the success of work activities (PT. Pelabuhan Indonesia III, 2010). The problem regarding port facilities in here is the port equipment. The problem is the number of available equipment in the port is not enough. Sometimes, when there is equipment that scheduled for maintenance, it is followed by the broken equipment. Therefore, the utility of the equipment cannot be maximized. However, these conditions will hold the releasing or displacement of container.

Based on those problems, the aim of this study is to analyze the effect of clearance and port equipment on long container dwelling time both partially and simultaneously and to identify most dominant variables between clearance and port equipment in the dwelling 
The Analysis of Clearance and Ports Equipment Toward Long Container Dwelling Time...

time of container in port. The paper is structured as follows: Section 2 presents a literature review of former studies/research related to the dwelling time of the container. Section 3 presents methodology, and Section 5 presents finding and discussion. Conclusions of the study are delineated in the final section 6 .

\section{Literature Review and Hypotheses Development}

In Sherly Luthfi Anita and Indra Asmadewa (2017) research with the title Dwelling Time Import Analysis at Tanjung Priok Port Through Application of Theory of Constraints, they found that pre-clearance stage took a long time to process of import clearance and the 10 (ten) of respondents agreed that the long container dwelling time caused by the clearance procedure. It happened because the difficult bureaucracy to understand.

In Ruwantono et al (2016) research entitled The Analysis of Unreachable Cause of the Dwelling Time Target Using Fault Tree Analysis Method, Case Study: Tanjung Priok Pelabuhan (Pelindo II), there were a gap of finding between Fault Tree Analysis (FTA) and DELPHI Method. FTA found that Post-Customs Clearance process is the root of the problem. But, based on the calculation of the weight of sixteen driving factors using the DELPHI method which is Pre-Customs Clearance stage.

In Analysis of the Role of Customs In the Effectiveness of the Application of Dwelling Time In Import Export Activities that made by Waty, Al Musadieq, and Supriono (2017), found that several obstacles in the implementation of Dwelling Time at the port of Tanjung Perak occurs in every process in Dwelling Time which includes the Pre Clearance process, Custom Clearance, and Post Clearance. The main obstacle faced is Pre Clearance process. It happened because users do not immediately fulfill their customs obligations.

In thesis of Tarigan (2018), with the title Analysis of Factors Affecting Container Dwelling Time in Belawan Port, Medan Based on the results of the research and discussion that have been carried out as a conclusion as follows: The average dwelling time in Belawan Port Medan is around 4 days while the government standard is 3 days, Variable calculation results that compare the dwelling time variation model between $X 1, X 2, X 3 ; X 1, X 2 ; X 1$, $X 3$ and $X 2, X 3$ shows that model $1(X 1, X 2, X 3)$ is the best with $R 2=0.997$ and significance $<0.05$. The most dominant factor affecting the dwelling time of containers in Belawan Port, Medan is pre clearance.

In Narindra et al (2015) research, discussed about The Analysis of Dwelling Time effects toward Revenue. Even the study did not find about clearance process, but in this study admitted that the factors that affecting dwelling time are Pre Clearance, Custom Clearance, and Post Clearance.

In study of Acceleration of Dwelling Time: Tanjung Priok Port's International Trade Performance Improvement Strategy created by Utami (2015) found that the preclearance process load was quite a large percentage compared to the custom clearance 
The Analysis of Clearance and Ports Equipment Toward Long Container Dwelling Time...

and post clearance stages. On average in 2013 , pre-clearance was $58 \%$, custom clearance was $24 \%$, post clearance was $17 \%$.

In Myung (2003), study about A comparison of service quality at major container ports: implications for Korean ports, found that Facilities available got result 0.8774 in cronbach alpha especially Availability of container handling equipment means port equipment affect the performance of port.

Last, Tongzon (1994) in Determinants of Port Performance and Efficiency study found that the stronger influence of terminal efficiency relative to other factors in the determination of port performance provides an empirical justification for giving top priority to improving terminal performance in the overall process of waterfront reform. The dominant contribution of crane productivity (TEUCH) to terminal efficiency justifies the need to put more emphasis on enhancements of crane productivity. The more improvement in equipment (crane, truck, and forklift) will increase the performance of the port.

Based on previous research, many of them use the clearance, namely pre, custom, and post-clearance as factors that influence the dwelling time and several comes with clearance as the dominant factor that affect dwelling time. This is due to the length of time it takes to process the required documents. However, giving best performance of the ports depends on the facilities and port equipment is one of the main facilities. The unavailable of port equipment due to poor management of the equipment will take another number of dwelling time of container for releasing/displacement them. Then, the research framework for this research as follows.

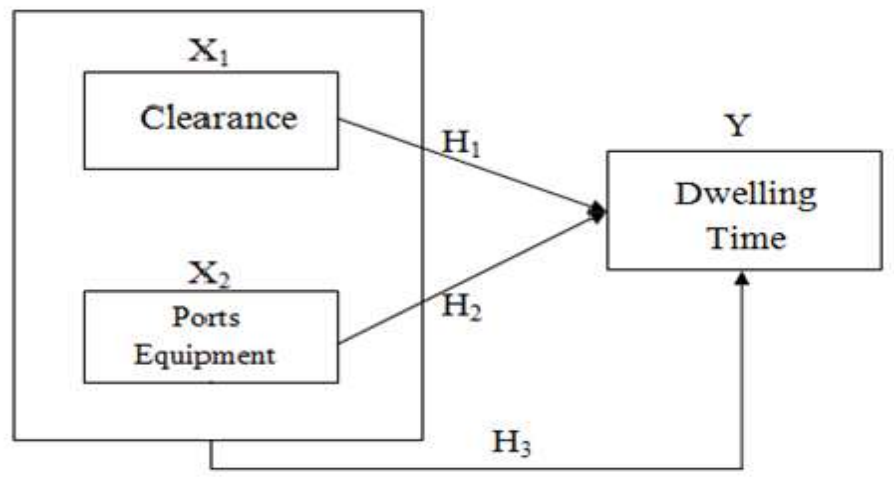

Figure 1 Research Framework

Source: Developed for research, 2019.

Description:

$\mathrm{H}_{1} \quad$ : There is effect of Clearance toward Dwelling Time individually. (H1: $\left.\beta 1 \neq 0\right)$

$\mathrm{H}_{2} \quad$ : There is effect of Port Equipment toward Dwelling Time individually. $(\mathrm{H} 2: \beta 2 \neq 0)$

$\mathrm{H}_{3}$ : There is effect of Clearance and Port Equipment toward Dwelling Time simultaneously. (H3: $\beta 3 \neq 0)$. 
The Analysis of Clearance and Ports Equipment Toward Long Container Dwelling Time...

\section{Research Method}

This research used explanatory research with a quantitative approach. According to Sugiyono (2014), explanatory research is a research method that explains the position of the variables studied and the effect of one of the variables with other variables.

Population is all values, both the result of calculations and measurements, both quantitative and qualitative, of certain characteristics regarding a complete and clear group of objects (Usman, 2006: 181).

Population in this research is data of custom clearance process (pre-clearance, custom clearance, and post custom clearance), ports equipment utilization, and dwelling time since 2001 - March 2019 produced by PT. Pelabuhan Indonesia III (Persero) Semarang Container Terminal (Terminal Petikemas Semarang) and Custom and Excise of Tanjung Emas.

The sample is partially taken from the overall population of the object under study and is considered to represent the entire population studied (Notoatmodjo, $2002: 79$ ).

The sample in this study is from January 2016 - March 2019. So, the total data for this study are thirty-nine months (data).

\section{Data Collection:}

1. Data Source. Secondary data is a secondary source is usually a scholar book, journal article, or digital or print document that was created by someone who did not directly experience or participate in the events or conditions under investigation. According to Hasan (2002: 82) secondary data is data which collected and submitted by person who did research from existed data sources. Secondary sources are not evidence per se, but rather, provide an interpretation, analysis, or commentary derived from the content of primary source materials and/or other secondary sources.

2. Data collection is a process of collecting information from all the relevant sources to find answers to the research problem, test the hypothesis and evaluate the outcomes. The writer will do another way to find the answer to the research problem, besides collect data from a company such as:

a. Interview

The interview will be conducted to the Operational employee of PT. Pelabuhan Indonesia III (Persero) Semarang Container Terminal.

b. Literature Review

The literature review is data collecting by the previous research. The literature review surveys scholarly articles, books, and other sources relevant to a particular area of research or study. 


\section{Utami, Sulistiyani, \& Azizah}

The Analysis of Clearance and Ports Equipment Toward Long Container Dwelling Time...

In quantitative study, data analysis method that used by this study is to answer the problems of the study or test the hypothesis that has been form before in proposal. Because the quantitative data, this research used software SPSS 16.0.

1. Descriptive statistics are the methods related to collection and presentation of data so as to provide useful information (Walpole, 1995). Descriptive statistics function to describe or give description of the object under study through sample or population data (Sugiyono, 2007). Data presented in descriptive statistics are usually in the form of size concentration of data (Kuswanto, 2012).

2. Multiple Linear Regression. Multiple Linear Regression analysis is a statistical tool for understanding the relationship between two or more variables (Rubinfeld, 1996). Multiple involves a variable to be explained-called dependent variable-and additional explanatory variables that are thought to produce or be associated with changes in the dependent variables.

The formula of multiple linear regressions is:

$$
Y=a+b 1 X 1+b 2 X 2+e
$$

Where:

$$
\begin{array}{ll}
\mathrm{Y} & =\text { Dependent variable (Dwelling Time) } \\
\mathrm{X} 1 & =\text { Independent variable (Clearance) } \\
\mathrm{X} 2 & =\text { Independent variable (Ports Equipment) } \\
\mathrm{a} & =\text { regression Constanta value } \\
\mathrm{b} & =\text { Regression Coefficient } \\
\mathrm{e} & =\text { Disturb Factor }
\end{array}
$$

Source: Sugiyono (2014).

The object of research is PT. Pelabuhan Indonesia III (Persero) Semarang Container Terminal (TPKS). Located on Jalan Coaster No. 10A, Tanjung Emas, Semarang. The data produced by the Operational Division of Semarang Container Terminal and Dwelling Time Team of Custom and Excises of Tanjung Emas.

\section{Result and Discussion}

Clearance of this study is seen from the time needed to complete the administrative process of releasing containers. The administrative process consists of 3 (three) stages, namely Pre-Clearance, Custom Clearance, and Post-Custom Clearance. From the total of time (days), the average will be obtained. Each process of releasing containers requires documents to be issued by agencies relating to goods in the containers. The graphical form, will show the trend of the length of time for processing the Clearance documents. 
The Analysis of Clearance and Ports Equipment Toward Long Container Dwelling Time...

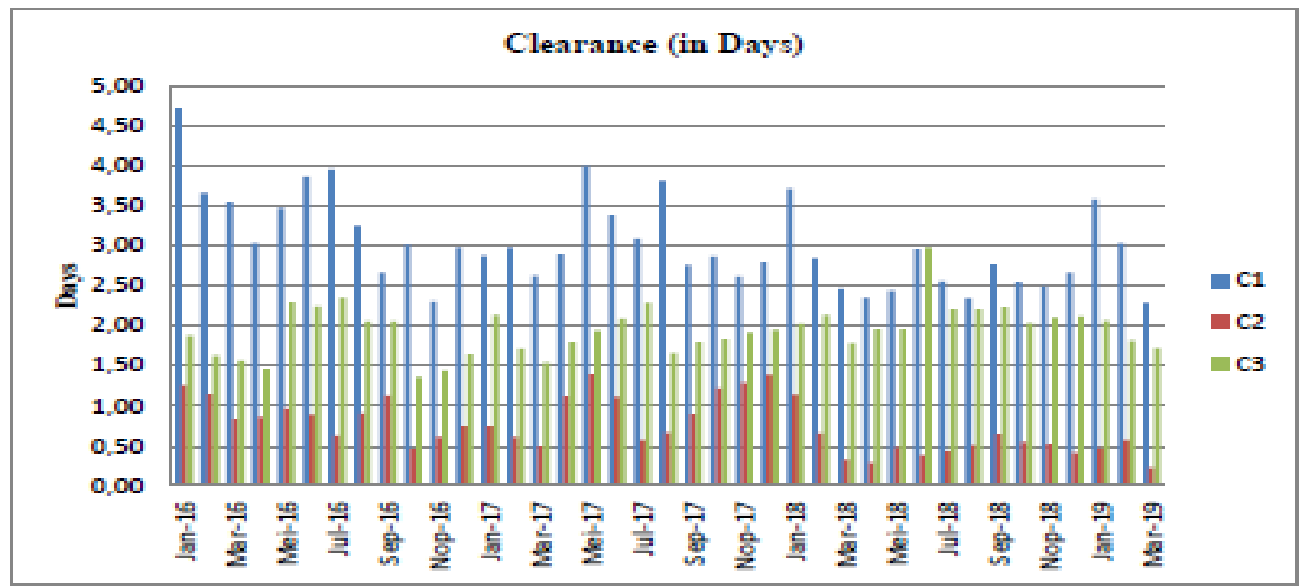

Figure 2 Clearance Stages (In Days)

Source: Custom and Excises of Tanjung Emas (2016-2019)

Where:

$\mathrm{C} 1$ = Pre-Clearance

$\mathrm{C} 2$ = Custom Clearance

C3 = Post-Custom Clearance

From these data it can be seen that the Pre-Clearance process takes longer than other processes.

Table 2 Port Equipment (In Percent)

\begin{tabular}{lllll}
\hline \multicolumn{1}{c}{ Month } & \multicolumn{3}{c}{ Year } & 2018 \\
\hline January & 35,63 & 2017 & 2018 & 43,47 \\
\hline February & 35,13 & 41,08 & 37,40 & 45,06 \\
\hline March & 40,36 & 37,92 & 40,98 & 49,07 \\
April & 37,53 & 32,89 & 42,08 & \\
May & 39,03 & 36,27 & 41,42 & \\
June & 39,53 & 28,71 & 45,49 & \\
July & 34,33 & 33,86 & 44,50 & \\
August & 33,82 & 31,06 & 43,42 & \\
September & 35,45 & 37,56 & 49,15 & \\
October & 28,86 & 34,40 & 47,33 & \\
November & 35,19 & 37,96 & 46,93 & \\
December & 34,83 & 31,52 & 50,74 & \\
\hline
\end{tabular}

Source: Secondary data processed, 2019

In the data, found some data that has an average below the specified standard. That can happen if it's due to damage or it's time for maintenance. Port equipment utility is a comparison between the numbers of ready equipment to be operated with a number of available equipment in a certain time period. When the company decides to have a standard of $40 \%$, it means that there are around $60 \%$ declaring that the equipment is not ready in 1 (one) month. It can be interpreted, that the damage or schedule of maintenance of equipment is included every month. 
The Analysis of Clearance and Ports Equipment Toward Long Container Dwelling Time...

\section{Descriptive Statistics}

From the value of descriptive statistics whether the minimum, the maximum, or the mean of dwelling time not yet met the national target of three days for maximum dwelling time. Clasiccal Assumption Test

\section{Normality Test}

Based on the Kolmogrov-Smirnov, the significance value is .871.740.990 of Clearance, Port Equipment and Dwelling Time. It can be concluded that the data is normally distributed because the data shows a significance value greater than 0.05 . Through P-Plot, the data spreads around the diagonal line and follows the direction of the diagonal line, this means that the data in this study came from populations that were normally distributed.

\section{Heterocedasticity Test}

In the data, each variables Clearance, and Port Equipmet has significance of .078 and .147, it can be seen that the significance value of each independent variable is greater than alpha, which is 0.05 . This means that in this study there was no heteroscedasticity.

\section{Multicollinearity Test}

Based on the test, Clearance has Tolerance of .905 and VIF of 1.105. meanwhile Equipment has Tolerance of .905 and VIF of 1.105, it can be seen that the Tolerance value in each equation is greater than 0.1 and the VIF value is less than 10. So it can be concluded on the model regression does not contain multicollinearity. This means that between the independent variables in this study do not interfere or influence each other.

\section{Autocorrelation Test}

The Durbin Watson value is 1,876 . So the $\mathrm{dW}$ value is between $\mathrm{dU}(1.5969)<\mathrm{dW}(1,876)$ $<4-\mathrm{dU}(4-1.5969=2.4031)$. Then it can be concluded that in this study there was no autocorrelation.

Multiple Linear Regression Analysis

Table 3 Multiple Linear Regression

\begin{tabular}{|c|c|c|c|c|c|c|}
\hline \multirow{2}{*}{\multicolumn{2}{|c|}{ Model }} & \multicolumn{2}{|c|}{$\begin{array}{l}\text { Unstandardized } \\
\text { Coefficients }\end{array}$} & \multirow{2}{*}{$\begin{array}{c}\text { Standardized } \\
\text { Coefficients } \\
\text { Beta } \\
\end{array}$} & \multirow[t]{2}{*}{$\mathbf{t}$} & \multirow[t]{2}{*}{ Sig. } \\
\hline & & $\mathrm{B}$ & Std. Error & & & \\
\hline \multirow[t]{3}{*}{1} & (Constant) & 4.101 & 1.030 & & 3.982 & .000 \\
\hline & Clearance & 1.402 & .290 & .609 & 4.828 & .000 \\
\hline & Equipment & -.028 & .018 & -.193 & -1.525 & .136 \\
\hline \multicolumn{5}{|c|}{ a. Dependent Variable: Dwelling Time } & & \\
\hline
\end{tabular}

Source: Secondary data processed, 2019 
Based on the SPSS calculation, the following multiple linear regression equations are obtained.

$$
\mathrm{Y}=4.101+1.402 \times 1-0.028 \times 2+\mathrm{e}
$$

Where:

$Y=$ Dwelling Time (Days)

$\mathrm{X} 1=$ Clearance (Days)

$\mathrm{X} 2=$ Port Equipment $(\%)$

$\mathrm{e}=$ Disturb Factor

Coefficient Determinant

The value of Adjusted $R$ Square is 0.452 . Means, variables $X 1$, and $X 2$ have a contribution (influence) of $45.2 \%$ to the variable $Y$. And around $54.8 \%$ is influenced by other variables outside the variables of clearance and equipment.

t-Test

The significant value of Clearance of 0.000 where less than 0.05 , then, $\mathrm{HO}$ is rejected. The t-count of 4.828 is greater than $\mathrm{t}$-table of 2.02619 . So, there is a significant effect of the Clearance variable on the Dwelling Time variable. Nevertheless, Port Equipment has a significance value of 0.136 where the value is more than $0.05 \mathrm{Then}, \mathrm{HO}$ is accepted. The $\mathrm{t}-$ count is -1.525 smaller than t-table of 2.02619 , and then $\mathrm{HO}$ is accepted. That is, there is no significant effect of variable port equipment utility on dwelling time variables.

F-Test

The significant value is 0,000 less than 0.05 , then $\mathrm{H} 0$ is rejected. Furthermore, the F-count value is 16.663 greater than F-table 3.26, and then $\mathrm{HO}$ is rejected. This means that the clearance and port equipment variables together have a significant effect on the Dwelling Time variable.

Based on the result, here are the discussions regarding the objection of the study:

a. The effect of clearance toward dwelling time of container in Semarang Container Terminal.

Based on the result of this study, clearance has a significant effect on dwelling time. The significant value is 0.000 and the t-count of 4.828 is greater than t-table of 2.02619. So, hypothesis 1 , There is the effect of Clearance toward Dwelling Time individually was accepted. The more clearance (on the process the documents), the more dwelling time in Semarang Container Terminal. In the clearance documents, there are three documents which need to be proceeding. Pre-clearance, custom clearance, and post-clearance. Therefore, to achieve the target of three days of dwelling time, one document should take the maximum days of one. This could happen if there is a system that integrated with all ministries or institution that related.

b. The effect of port equipment toward dwelling time of container in Semarang Container Terminal. 
The Analysis of Clearance and Ports Equipment Toward Long Container Dwelling Time...

In the result of port equipment, unfortunately, port equipment has no significant effect on dwelling time because the significant value is greater than 0.05 . Therefore, hypothesis 2, There is the effect of Port Equipment toward Dwelling Time individually was rejected. This can happen because from the very first place there is a different standard that the company applied with the standard of Directorate General of Sea Transportation. According to UM.002/38/18/DJPL of 2011, the standard operational equipment of Semarang Container Terminal is $80 \%$. Meanwhile, the standard that decides in the company is $40 \%$. There is a huge gap in the standard. It is caused by data that has a value below the standard. Even though the result is insignificant, port equipment has the main role of in port performance. In fact, port performance depends on Waiting Time (Ship) and Dwelling Time (container). So, in the real field port equipment should have a significant value to dwelling time. Because all activities that happen in port need supporting from port facilities. Facilities can be the main key to the success of work activities (PT. Pelabuhan Indonesia, 2010).

c. The effect of clearance and port equipment toward dwelling time of container in Semarang Container Terminal.

Both Clearance and Port equipment have significant value are 0,000 less than 0.05 . Furthermore, the F-count value is 16.663 greater than F-table 3.26. Therefore, Hypothesis 3 with there is an effect of Clearance and Port Equipment toward Dwelling Time simultaneously was accepted. This means that the process of clearance and port equipment together have a significant effect or influence on the long Container Dwelling Time. So, the company has to take the strategy to avoid the difficult bureaucracy of clearance documents or the ineffective port equipment.

d. The most dominant variables between clearance and port equipment in the dwelling time of container in ports.

Based on the analysis result, Clearance variable is dominant than Port Equipment variable. It shows that Clearance has a significant value of 0.000 than Port Equipment is 0.136 . Where, the variable which has significant of $0.000<0.05$, so the variable has a (significant) effect on the dependent variable. Therefore, Clearance is more dominant than Port Equipment.

\section{Conclusion}

Clearance have a significant value and positive effect toward Long Container Dwelling Time in PT. Pelabuhan Indonesia III (Persero) Semarang Container Terminal. Where the longer it takes to process the clearance, the more dwelling time of the container will be. It happens because importer still try to understand all the requirements and they need time to complete all the documents. Meanwhile, Port Equipment has no significant value and negative effect toward Long Container Dwelling Time. Eventually, this result has opposite value with the reality. It the field, if the utility of the port equipment is in the best conditions, it will drag into the best performance of the operator. 
The Analysis of Clearance and Ports Equipment Toward Long Container Dwelling Time...

Simultaneously, Clearance and Port Equipment has significant value and effect the long container dwelling time. It proves that both of variables will affect the dwelling time weather press or escalate it. Clearance and equipment port had contributed to this research of 45.2 percent on the dwelling time and around 54.8 percent is calculated by other variables which are not counted. The last, Clearance gives more dominant effect than Port Equipment, showed in the significant value.

\section{Recommendation}

Based on the results of this study, it can be seen that there are two independent variables that influence the Dwelling Time in PT. Pelabuhan Indonesia III (Persero) Semarang Container Terminal namely Clearance and Port Equipment. The suggestions that could give to the company are as follows; PT Pelabuhan Indonesia III (Persero) Semarang Container Terminal needs to conduct a socialization or Focus Group Discussion with several business actors and local Custom and Excises regarding the procedure of Indonesian Single Window. The company needs to take strategic steps to avoid damage to port equipment and adjust maintenance schedules for port equipment in accordance with procedures or standards that apply in PT. Pelabuhan Indonesia III (Persero) Semarang Container Terminal. Add more port equipment as substitution and training for the operator. Providing training regarding the operation of port equipment so that operators can adapt to more sophisticated equipment. Benchmarking to the port companies either in Indonesia or abroad.

\section{References}

Anita, S. L., \& Asmadewa, I. (2017). Analisis Dwelling Time Import Pada Pelabuhan Tanjung Priok Melalui Penerapan Theory of Containts. Jurnal Perspektif Bea dan Cukai, 1(1), 73-87. https://doi.org/10.31092/ipbc.v1i1.125

Hasan, M. I. (2002). Pokok - Pokok Materi Penelitian dan Aplikasinya. Bogor: Ghalia Indonesia.

Kuswanto, D. (2012). Statistika Untuk Pemula dan Orang Awam. Jakarta: Laskar Aksara.

Ministry of Trade. (2018). Statistik Perdagangan Ekspor dan Impor di Indonesia. Received from https://www.kemendag.go.id

Narindra, R. A., Musadieq, M. A., \& Supriono. (2015). Analisis Pengaruh Dwelling Time Terhadap Pendapatan. Jurnal Administrasi Bisnis, 41(1), 51-56. http://administrasibisnis.studentjournal.ub.ac.id/index.php/jab/article/view/1633

Peraturan Menteri. (2016). Nomor PM 116 tentang Pemindahan Barang yang Melewati Batas Waktu Penumpukan.

Peraturan Pemerintah. (2006). Undang-Undang No. 17 Tahun 2006 Tentang Kepabeanan.

PT. Pelabuhan Indonesia III. (2010). Kinerja Pelabuhan Indonesia. Surabaya: PT. Pelabuhan Indonesia III.

Rubinfeld, D. L. (1999). Reference Guide on Multiple Regressions. Barkeley: University of California.

Sanjaya, A. C., Njatrijani, R., Saptono, H. (2017). Pelaksanaan Pengurusan Dokumen Tentang Impor Barang Terkait Dengan Dwellingtime Di Pelabuhan Panjang Bandar Lampung. Diponegoro Law Journal, Volume 6 (2), 5-12. Received from https://ejournal3.undip.ac.id/index.php/dlr/article/view/19561 
Sugiyono. (2007). Metode Penelitian Pendidikan Pendekatan Kuantitatif, Kualitatif, dan R\&D. Bandung: Alfabeta.

Sugiyono. (2014). Metode Penelitian Kuantitatif Kualitatif dan R\&D. Bandung: Alfabeta.

Tarigan, B. (2018). Analisis Faktor-Faktor yang Mempengaruhi Dwelling Time Peti Kemas di Pelabuhan Belawan Medanll. Jurnal Teknik Sipil USU, 3(2), 2-4. Received from https://jurnal.usu.ac.id/index.php/jts/article/view/24308

United Nations Conference on Trade and Development (UNTCAD). (2017). World Investment Report.

Usman, A. (2006). Metodologi Penelitian Sosial. Jakarta: Bumi Aksara.

Utami, W. S. (2015). Analyze The Policy Strategies To Accelerate The Dwelling Time At Tanjung Priok Portll. Economics Development Analysis Journal, Volume 4(1), 82-90.

Walpole, R. E. (1995). Pengantar Statistika edisi ke-3. Jakarta: Gramedia Pustaka Utama.

Waty, S. A., Al Musadieq, M., \& Supriono. (2017). Analisis Peranan Bea Cukai Dalam Efektivitas Penerapan Dwelling Time Pada Kegiatan Ekspor Impor Medan. Jurnal Administrasi Bisnis, 51(1), 159-168. Received from

http://administrasibisnis.studentjournal.ub.ac.id/index.php/jab/article/view/2120

World Bank. (2017). World Bank Seaport Toolkit. (2nd edition). Washington, USA: World Bank 